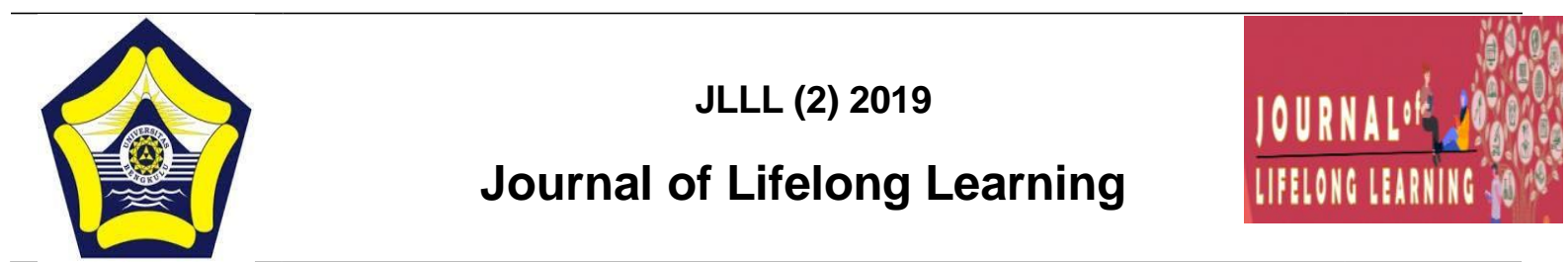

\title{
PELAKSANAAN PEMBELAJARAN MENJAHIT LEVEL SATU PADA LEMBAGA KURSUS DAN PELATIHAN (LKP)
}

\author{
Kumala Dewi ${ }^{1}$, Agus Z Rahmad ${ }^{2}$, Ririn Gusti ${ }^{3}$ \\ ${ }^{1}$ Nonformal Education, University of Bengkulu, Indonesia, kumaladewi@gmail.com \\ ${ }^{2}$ Nonformal Education, University of Bengkulu, Indonesia, aguszainal1823@gmail.com \\ ${ }^{3}$ Nonformal Education, University of Bengkulu, Indonesia, riringusti@unib.ac.id
}

\begin{abstract}
The objectives of this study were: (1) The purpose of this stady was to determine the learning objectives of sewing courses at level one in the Mayang Sari course Institusi in Bengkulu City (2) Knowing the source of learning sewing courses at level one at the Mayang Sari training institusi and city of Bengkulu (3) Knowing the sewing course learning strategy at level one at the Mayang Sari Course and training institute in Bengkulu City (4) Know the learning media for sewing courses at level one at the Mayang Sari course and training institusi in Bengkulu (5) Know the evaluation of learning sewing courses at level one in the Mayang Sari training course institute in Bengkulu. The research method used is a qualitative method with a descriptive approach participants in the research were Ibu Sorehalela as the chairperson of the Mayang Sari training curriculum. Data collection techniques used were non-participant observation, structured, interviews, and documentation. To test the validity and reliability of the data using triangulation of sources, techniques and time. Based on the analysis that has been done that the management of sewing courses at the Mayang Sari training institute and courses in the city of Bengkulu. (1) The goal of the sewing course is to improve the personal and social qualities of each individual learning, to provide a sense of security and comfort while learning to $\operatorname{sew}(2)$ learning resources at LKP mayang sari are assence of digital media, guidebooks and references from fellow sew (3) the sewing course learning strategies for LKP mayang are essentially giving the theory first to practice while the method used is discourse, discussion, practice and simulation methods (4) the media that we use for sewing classes in LKP mayang is essentially the set of them one computer, printer one unit,laptop 1 unit LCD 1 unit and has the means and infrastructure of a course room, office building, sewing machine and machine, (5) the evaluation for the sewing course is done with the written exam and the practice exam of participants learning to sew.
\end{abstract}

Keywords: Implementation of the sewing course

(C) 2019 Dept of Nonformal Education UNIB

Address correspondence:

e-ISSN

Jl. W.R. Supratman, Kandang Limun, Muara Bangka Hulu,

Kota Bengkulu, Bengkulu 38371 


\section{PENDAHULUAN}

Lembaga Pelatihan dan Kursus adalah salah satu bentuk satuan pendidikan Nonformal yang diselenggarakan bagi masyarakat yang memerlukan bekal pengetahuan, keterampilan, kecakapan hidup, dan sikap untuk mengembangkan diri, mengembangkan profesi, bekerja, usaha mandiri, dan/atau melanjutkan pendidikan ke jenjang yang lebih tinggi. UU Nomor 20 Tahun 2003 tentang sistem pendidikan nonformal mengamatkan bahwa fungsi pendidikan nonformal (PNF) adalah sebagai pengganti, penembah, dan pelengkap pendidikan formal, dalam rangka mendukung pendidikan sepanjang hayat untuk mengembangkan potensi peserta didik dengan penekanan pada penguasaan pengetahuan dan keterampilan fungsional serta pengembangan sikap dan kepribadian professional. Dalam pelaksanaan amanat Undang-Undang tersebut, Direktorat Jendral Pendidikan Luar Sekolah melembagakan Direktorat Pembinaan Kursus dan Kelembagaan. Upaya-upaya dalam meningkatkan SDM yang telah dipelajari selama ini dengan berbagai cara, diantaranya meningkatkan pengetahuan, keterampilan, sikap dan kemampuan masyarakat.

Tujuan dari penyelenggaraan kursus menjahit di lembaga Kursus Pelatihan Mayang Sari ini adalah : 1). Dapat menciptakan lapangan kerja/unit-unit kerja baru serta meningkatkan taraf hidup, 2). Menyediakan tenaga terampil, 3). Membantu program pemerintah dalam mengurangi angka pengangguran dan memberantas kemiskinan. LKP Mayang Sari tergolong maju dan di minati oleh masyarakat dikarenakan memiliki keunggulan diantaranya lulusan menjahit di LKP Mayang Sari menerapkan keahlian yang telah dimiliki dengan membuka usaha sendiri, ada yang direkrut oleh ibu Sorehalela untuk menjadi tenaga kerja di LKP Mayang Sari dan ada juga instansi yang bekerja sama dengan LKP Mayang Sari untuk penyaluran tenaga kerja apabila ada instansi lain yang membutuhkan tenaga kerja. Setelah mengikuti proses pembelajaran kursus warga belajar dianjurkan untuk mengikuti Uji Kompetensi sehingga pengakuan akan keterampilannya lebih terjamin.

\section{METODE}

Dalam penelitian ini, peneliti menggunakan metode penelitian kualitatif dengan data yang bersifat deskriptif. Menurut Sugiyono (2019:26) mengemukakan bahwa penelitian kualitatif adalah metode penelitian yang berlandasan pada filsafat postpositivisme, ( berbagai lawannya adalah eksperimen) dimana penelitian adalah instrumen kunci, tekhnik pengumpulan data dilakukan secara tri anggulasi (gabungan), analisis data bersifat induktif/ kualitatif, dan hasil penelitian kualitatif lebih menekankan makna dari pada generalisasi.

\section{HASIL DAN PEMBAHASAN}

Tujuan pembelajaran kursus menjahit adalah memperbaiki kualitas diri dan kualitas sosial setiap warga belajar, memberikan rasa aman dan nyaman saat belajar menjahit, sumber belajar di LKP Mayang Sari terdiri dari digital media, buku panduan dan referensi dari sesama teman menjahit,strategi pembelajaran kursus menjahit pada LKP Mayang Sari yaitu memberikan teori terlebih dahulu baru praktek sedangkan metode yang digunakan yaitu metode ceramah, diskusi, praktik dan simulasi, media yang digunakan dalam pembelajaran kursus menjahit di LKP Mayang Sari yaitu seperangkat IT 
diantaranya komputer 1 unit, printer 1 unit, laptop 1 unit LCD 1 unit dan mempunyai sarana dan prasarana yang berupa ruang kursus, gedung kantor dan mesin jahit, mesin obras,evaluasi pembelajaran dilakukan dengan ujian tertulis dan ujian praktek pada peserta belajar menjahit.

\section{PENUTUP}

\section{KESIMPULAN}

Dari hasil penelitian dilapangan tentang pelaksanaan pembelajaran kursus menjahit level satu di LKP Mayang Sari Kota bengkulu, berdasarkan masalah, tujuan, hasil penelitian dan pembahasan dapat disimpulkan bahwa:

1. Pertama, tujuan pembelajaran kursus menjahit di LKP Mayang Sari Kota Bengkulu yaitu untuk mengurangi pengangguran, dengan peserta belajar bisa menjhit itu artinya peserta belajar tersebut bisa menambah keahlian nya dan bisa bekerja ataupun bahkan membuka lapangan kerja sendiri.

2. Kedua, sumber belajar kursus menjahit di LKP Mayang Sari, terdiri dari digital media, buku panduan, referensi dari sesama teman menjahit dan teman-teman yang biasa mendesain baju.

3. Ketiga, strategi pembelajaran kursus menjahit pada level satu di LKP Mayang Sari Kota Bengkulu, metode yang digunakan dalam kursus menjahit yaitu metode teori, metode tanya jawab antara instruktur dan peserta yang digunakan pada saat teori maupun praktek,

4. Keempat, media pembelajaran kursus menjahit pada level satu di LKP Mayang Sari Kota Bengkulu yaitu modul berupa buku panduan yang berisi teori pembelajaran kursus menjahit, dan mempunyai seperangkai IT diantaranya komputer 1 unit, printer 1 unit, laptop 1 unit LCD 1 unit, mesin jahit dan yang dapat digunakan oleh pengelola LKP untuk mengelola lembaga itu sendiri.

5. Kelima, tujuan dari evaluasi pembelajaran kursus menjahit pada level satu di LKP Mayang Sari Kota Bengkulu yaitu evaluasi pembelajaran yang dilakukan dengan ujian tertulis dan ujian praktek pada peserta belajar menjahit di LKP Mayang Sari.

\section{REFERENSI}

Arifin, Zainal. 2013. Evaluasi Pembelajaran. Bandung : PT Remaja Rosdakarya

Dimyati dan Mujiono. 2009. Belajar dan Pembelajaran. Jakarta : Rineka

Gredler, Margaret E. Bell. (Penerjemah Mandarin). 1991. Belajar danMembelajarkan. Jakarta : C.V. Rajawali dan PAU-UT.

Hery, Rahyudi. 2012. Teori-Teori Belajar dan aplikasi pembelajaran motorik. Bandung. PT Nusantara

Iskandar. 2009. Metodelogi Pendidikan Kualitatif. Jakarta. Gaung Persada

Kaswan. 2016. Pelatihan dan pengembangan untuk meningkatkan SDM. Bandung : Alfabeta

Mojone \& Wildavsky. 2004. Konsep Belajar dan Pembelajaran. Jakarta : CV Usaha Nasional

Lexy J. Moleong. 2010. Metode Penelitian Kualitatif. Bandung : PT Remaja Rasdokarya 
Rusman. 2017. Belajar dan Pembelajaran. Jakarta : PT Kharisma Putra Utama Sewarno. Wiji. 2006 Dasar-Dasar Ilmu Pendidikan. Jogyakarta : Ar-Ruzz Media

Siregar, JR.2013. Komponen-komponen pembelajaran (Http://Renoldsiregar.

Soelaeman, J. 1999. Konsep Dasar Pendidikan Luar Sekolah. Jakarta: Bumi Aksara

Sugiyono. 2014. Metode Penelitian, Kuantitatif, Kualitatif dan r \& d Bandung : PT Alfabeta.

Sudjana. 2010. Manajemen Pendidikan Luar Sekolah. Bandung : Nusantara Press Yayasan Islam Nusantara.

Poerwo, Darmanto. 2002. Kamus Besar Bahasa Indonesia. Jakarta : Balai Pustaka

Undang-undang RI No.20 Tahun 2003. Tentang Sistem Pendidkan Nasional. Jakarta cemerlang. 